\title{
PERANCANGAN SISTEM INFORMASI MONITORING PELAYANAN KARANTINA TUMBUHAN "SiMERAQ"
}

\author{
Merry Agustina ${ }^{1}$, Tri Rizqi Ariantoro ${ }^{2}$ \\ Dosen Universitas Bina Darma ${ }^{1}$, Dosen STIK Bina Husada ${ }^{2}$ \\ Jalan Jenderal Ahmad Yani No. 3 Palembang ${ }^{1}$ \\ Jalan Syech Abd Somad No. 28 Palembang ${ }^{2}$ \\ Sur-el : merry_agst@binadarma.ac.id ${ }^{1}$, tririzqiariantoro@yahoo.com ${ }^{2}$
}

\begin{abstract}
Public services in government agencies are starting to change from a direct face-toface way that the process must be back and forth if there is a shortage of files and take a long time, turning into a service online. In order to improve the satisfaction of public service in government agencies, especially the agricultural quarantine Hall of Class II Cilegon, then the process of application of plant quarantine import, export and domistic can be done online using the system, So that the quarantine submission process can be monitored in realtime. This information system consists of two parts, namely the first part is the front end used by the community in monitoring the process of filing plant quarantine. The second part is the back end used by the file verification Officer, the functional coordinator in delivering the task letter to the field officer, the Laboratory officers provide laboratory verification results, the Treasurer sends Billing payments to the community and head of the hall in monitoring every process of quarantine submission from the community. The back end uses the website.
\end{abstract}

\section{Keywords: Monitoring, Services, Plant Quarantine, Information Systems, Android}

\begin{abstract}
Abstrak : Pelayanan publik di instansi pemerintah mulai berubah dari cara tatap muka langsung yang prosesnya harus bolak balik jika terdapat kekurangan berkas dan memakan waktu yang lama, berubah menjadi pelayanan secara online. Guna meningkatkan kepuasan pelayanan publik di instansi pemerintah khususnya Balai Karantina Pertanian Kelas II Cilegon, maka proses pengajuan pelayanan karantina tumbuhan impor, ekspor dan domistik dapat dilakukan secara online dengan menggunakan sistem, sehingga proses pengajuan karantina dapat di pantau secara realtime. Sistem informasi ini terdiri dari dua bagian yaitu bagian pertama merupakan bagian front end yang digunakan oleh masyarakat dalam memonitor proses pengajuan karantina tumbuhan. Bagian ke-dua merupakan bagian back end yang digunakan oleh petugas verifikasi berkas, koordinator fungsional dalam memberikan surat tugas kepada petugas lapangan, petugas laboratorium memberikan hasil pengecekan laboratorium, bendahara mengirimkan billing pembayaran kepada masyarakat dan kepala balai dalam pemantauan setiap proses pengajuan karantina dari masyarakat. Bagian back end menggunakan website.
\end{abstract}

Kata kunci: Monitoring, Pelayanan, Karantina Tumbuhan, Sistem Informasi, Android

\section{PENDAHULUAN}

Teknologi Informasi dan Komunikasi saat ini telah berkembang dengan pesatnya. Berbagai kemajuan di bidang teknologi Informasi dan komunikasi memberikan berbagai pengaruh bagi kehidupan manusia. Keberadaan Teknologi infomasi membarikan banyak kemudahan dalam menyelesaikan pekerjaan, mempermudah komunikasi serta menyediakan banyak informasi kepada penggunanya. Informasi memiliki pengertian sebagai proses lebih lanjut dari data yang sudah memiliki nilai tambah, data yang telah diolah menjadi sebuah bentuk yang berarti bagi penerimanya dan bermanfaat bagi pengambilan keputusan saat ini atau saat mendatang [1].

$$
\text { Perangkat lunak yang unggul dapat }
$$
memberikan informasi sesuai dengan kebutuhan penggunanya. Informasi adalah hasil pengolahan 
sehingga sehingga menjadi bentuk yang pentong bagi penerimanya dan mempunyai kegunaan sebagai dasar dalam pengambilan keputusan yang dapat dirasakan akibatnya secara langsung saat itu juga atau secara tidak langsung pada saat mendatang [2]. Seiring dengan kemajuan teknologi, pola pelayanan publik di instansi pemerintah mulai berubah dari cara tatap muka langsung yang prosesnya harus bolak balik jika terdapat kekurangan atau kesalahan berkas dan memakan waktu yang lama, ditingkatkan menjadi pelayanan secara online sehingga transparansi dan akuntabilitas pelayanan publik lebih jelas termonitor dan dapat dilakukan secara realtime serta proses pelayanan dapat dilakukan secara cepat [3]. Guna meningkatkan kepuasan pelayanan publik di instansi pemerintah khususnya Balai Karantina Pertanian kelas II Cilegon, maka proses pengajuan pelayanan karantina tumbuhan impor, ekspor dan domistik dapat dilakukan secara online dengan menggunakan sistem informasi monitoring pelayanan karantina tumbuhan, sehingga proses pengajuan karantina dapat di pantau secara realtime. Dengan menggunakan sistem informasi ini, dapat mengurangi interaksi langsung antara masyarakat pengguna jasa dan Balai Karantina Pertanian Kelas II Cilegon, dengan berkurangnya interaksi langsung maka profesionalitas petugas balai karantina tetap terjaga.

Sistem informasi ini terdiri dari dua bagian yaitu bagian pertama merupakan bagian front end yang digunakan oleh masyarakat dalam memonitor proses pengajuan karantina tumbuhan impor, ekspor dan domistik mulai dari proses pengajuan, persetujuan pengajuan, kedatangan kapal, pengecekan oleh petugas, hasil laboratorium, billing pembayaran dan pengambilan sertifikat, kemudian masyarakat dapat melakukan komunikasi dengan petugas Balai Karantina Pertanian kelas II Cilegon terkait dengan proses pengajuan karantina melalui fitur chatting yang telah disediakan. Kemudian bagian front end juga digunakan oleh petugas lapangan dalam menerima surat tugas dan dalam pelaksanaan dan pembuatan laporan. Bagian front end menggunakan aplikasi android yang di instal pada smartphone masyarakat dan petugas lapangan. Bagian ke-dua merupakan bagian back end yang digunakan oleh petugas verifikasi berkas, koordinator fungsional dalam memberikan surat tugas kepada petugas lapangan, petugas laboratorium memberikan hasil pengecekan laboratorium, bendahara mengirimkan billing pembayaran kepada masyarakat dan kepala balai dalam pemantauan setiap proses pengajuan karantina dari masyarakat. Bagian back end menggunakan website.

Dalam membangun sistem informasi monitoring pelayanan karantina tumbuhan ini menggunakan metode pengembangan sistem waterfall. Penggunaan sistem informasi monitoring pelayanan karantina tumbuhan menjadi solusi dalam meningkatkan akuntabilitas dan transparansi pelayanan publik, mengurangi interaksi langsung antara masyarakat dan petugas balai karantina dan memonitor proses pengajuan karantina tumbuhan impor, ekspor dan domistik. 
Beberapa penelitian yang menjadi rujukan dalam perancangan sistem ini salah satunya adalah penelitian yang dilakukan oleh Mudjahidin dan Nyoman Dita Pahang Putra dengan judul Rancang Bangun Sistem Informasi Monitoring Perkembangan Proyek Berbasis Web Studi Kasus di Dinas Bina Marga dan Pemantusan, penelitian ini menghasilkan sebuah aplikasi WEB dan WAP yang mampu mengolah data perkembangan proyek di Dinas Bina Marga dan Pemantusan [4]. Penelitian lain dilakukan oleh Rohayani, Darius Antoni dan Soekarno Putra dengan judul Pengembangan Perangkat Lunak E-Monitoring Kebersihan Kereta Penumpang Wilayah Divisi Regional III Palembang Berbasis Android. Penelitian ini menghasilkan sebuah aplikasi yang dapat menyajikan informasi tentang tanggung jawab kebersihan baik di perjalanan, keberangkatan dan kedatangan [5].

\section{METODOLOGI PENELITIAN}

\subsection{Metode Penelitian}

Metode Penelitian dapat diartikan langkah-langak atau cara yang dapat digunakan untuk mencapai tujuan yang dicapai dalam kaitannya dengan pelaksanaan kegiatan penelitian dengan teknik atau alat tertentu. Metode yang digunakan dalam penelitian ini adalah metode Development Research. Metode Development Reseach adalah metode yang digunakan dalam suatu kegiatan penelitian yang bertujuan dan berusaha mengembangkan atau yang sudah ada atau diketahui [6].
Penelitian ini dilakukan pada Balai Karantina Pertanian Kelas II Cilegon yang beralamat J1 Raya Transit Cikuasa Pantai Merak Cilegon Banten 42438

\subsection{Metode Pengembangan Sistem}

Penelitian ini menggunakan metode pengembangan prototyping. Metode prototyping merupakan sebuah paradigma baru dalam pengmebangan sistem ddan aplikasi, tidak hanya sekedar suatu evolusi dari metode pengembangan sistem informasi yang sudah ada, tetapi sekaligus merupakan revolusi dalam pengembangan sistem informasi [7]. Tahapan dalam prototyping terdiri dari; 1) Pengumpulan kebutuhan, pada tahap ini Pelanggan dan pengembang bersama-sama mendefiniskan format dan kebutuhan perangkat lunak secara keseluruhan, mengidentifikasikan semua kebutuhan, dan garis besar sistem yang akan dibuat, 2) Membangun prototyping, yang dilakukan pada tahap ini adalah membuat desain sementara yang berpusat pada penyajian kepada pelanggan, misalnya; dengan membuat contoh input dan output, 3) Evaluasi prototyping, jika prototype yang sudah dibangun sesuai dengan keinginan pelanggan maka dilakukan evaluasi. JIka sudah sesuai akan dilanjutkan ketahap pengkodean (coding) namun jika belum sesuai maka akan diperbaik dengan mengulang kembali tahap 1,tahap 2 dan tahap 3, 4) Mengkodekan Sistem, tahap ini lakukan jika prototype yang dibuat sudah diterima dan disepakati yang dilanjutkan dengan pengkodean dengan bahasa pemrograman yang sesuai, 5) Menguji Sistem, tahap ini dilakukan untuk mengetahui 
performance dari sistem yang dibangun. Pengujian sistem dilakukan dengan metode Black Box, 6) Evaluasi Sistem, tahap ini dilakukan untuk mengetahui apakh sistem yang dibangun telah sesuai dengan yang diharapkan. Jika sudah memenuhi dapat dilakukan tahap selanjutnya, namun jika tidak maka perlu dilakukan pengulangan pada tahap 4 dan tahap 5, 7) Menggunakan Sistem, yaitu sistem yang dibangun siap digunakan oleh pelanggan setelah tahap pengujian berhasil dan diterima oleh pelanggan.

\section{HASIL DAN PEMBAHASAN}

\subsection{Perancangan Sistem}

Langkah awal yang dilakukan dalam membangun suatu sistem atau perangkat lunak adalah melakukan perancangan sebagai implementasi tahap analisis melalui perencanaan sistem. Dalam perencanaan sistem dapat diidentifikasi dan diketahui kebutuhan dari sistem yang akan dibangun meliputi kebutuhan perangkat lunak dan perangkat keras. Sehingga sistem yang akan dibangun nantinya sesuai dan dapat menjadi solusi dari permasalahn yang ada pada sistem yang lama dan pada akhirnya tujuan dari pembuatan sistem yang baru tercapai.

Dalam perancangan sistem informasi monitoring pelayanan karantina tumbuhan "SiMERAQ" ini, pemodelan sistem di menggunakan use case diagram. Dengan menggunakan use case diagram, interaksi antara pengguna sistem dengan sistem dapat dijelaskan dengan rinci dan mudah.

\section{Use case Diagram}

Use case diagram berfungsi untuk menggambarkan dan memodelkan serta mengorganisasi pada sistem informasi monitoring pelayanan karantina tumbuhan, dimana pembuatan diagram ini terdiri dari yaitu admin website, verifikator, kepala balai, koordinator fungsional (KorFung), kepalaa seksi, laboran, bendahara, petugas lapangan dan masyarakat (pemohon). Sehingga apa yang diperbuat oleh aktor tersebut pada sistem terlihat dengan jelas yang disajikan pada gambar-gambar berikut ini.

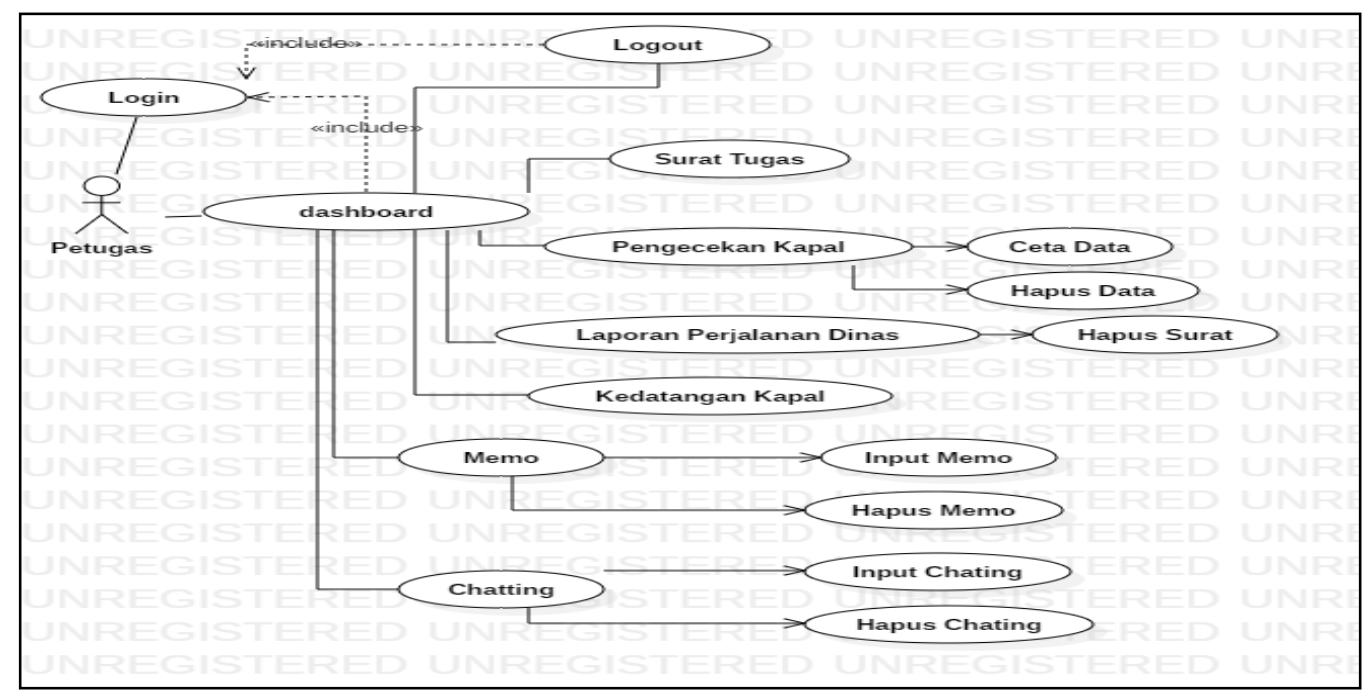

Gambar 1. Use Case Diagram Petugas/Admin 


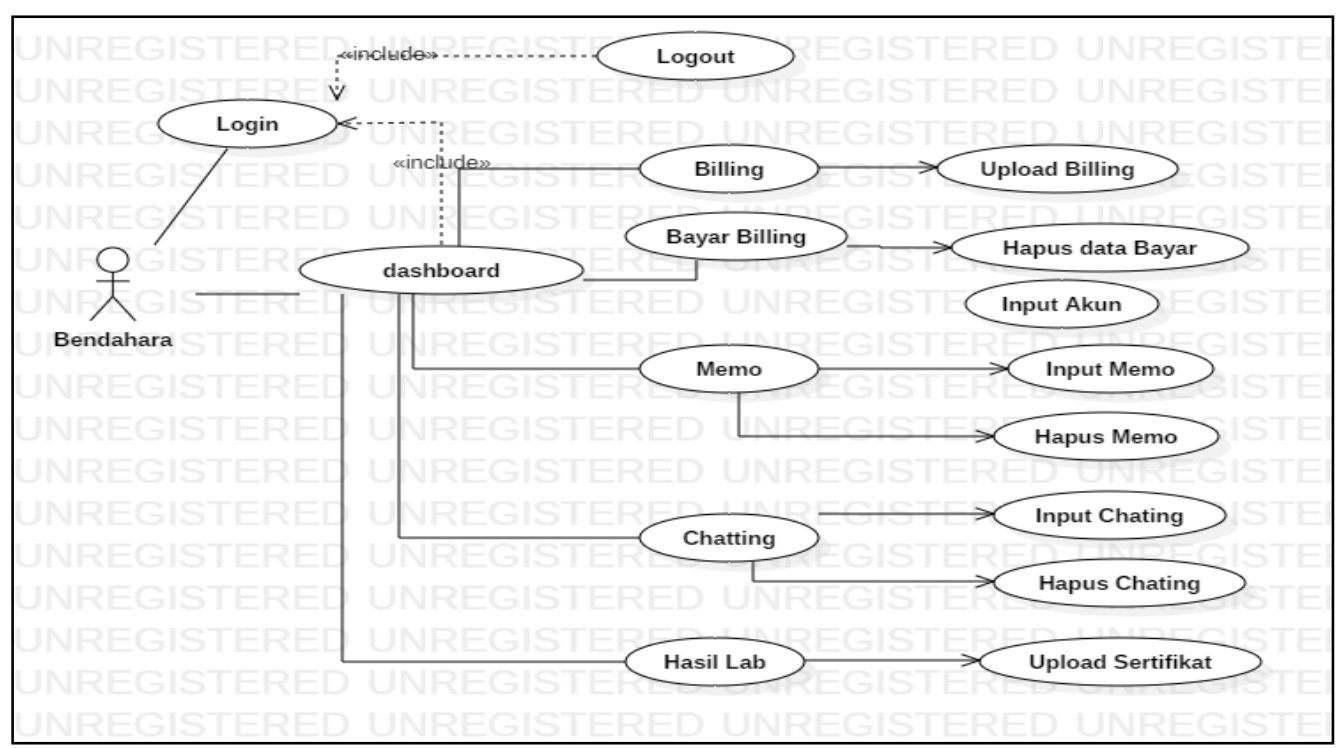

Gambar 2. Use Case Diagram Bendahara

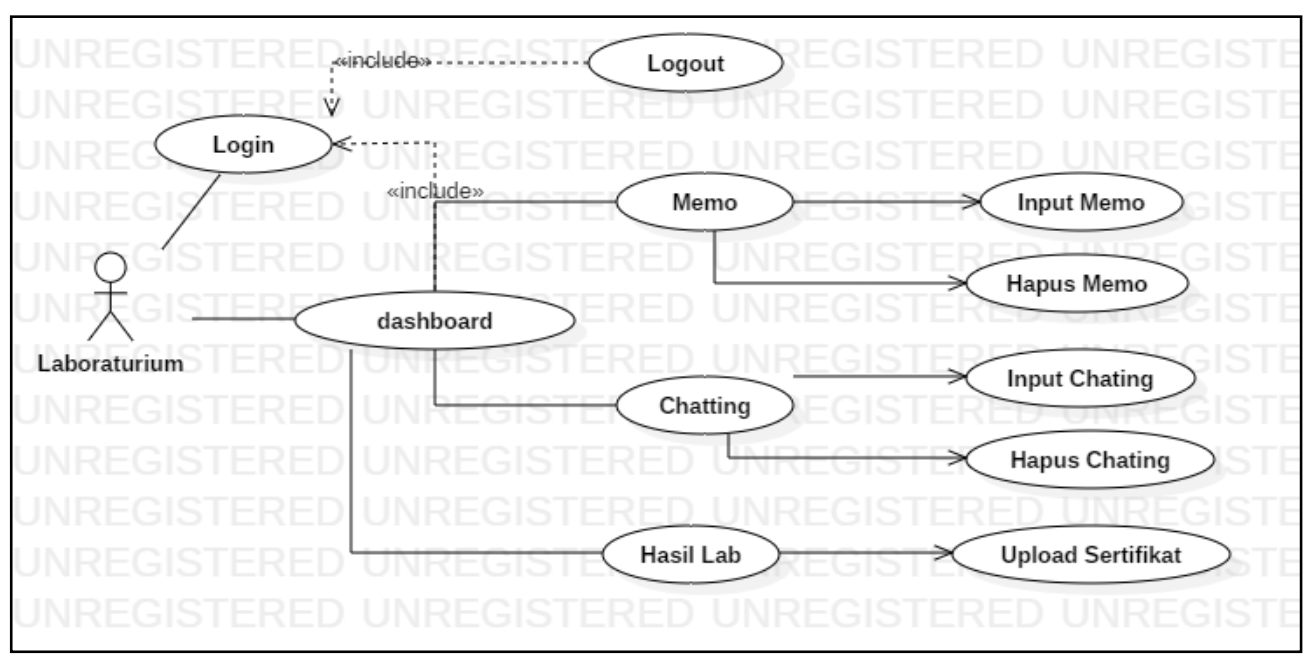

Gambar 3. Use Case Diagram Laboran

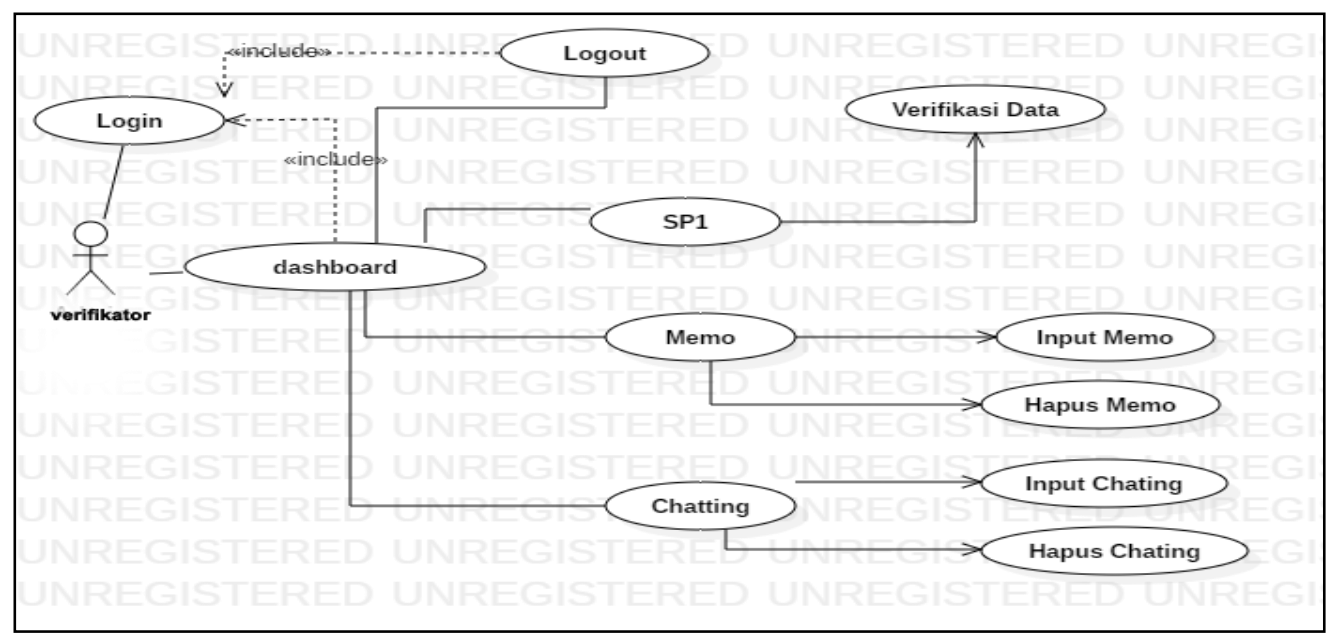

Gambar 4. Use Case Diagram Verifikator 


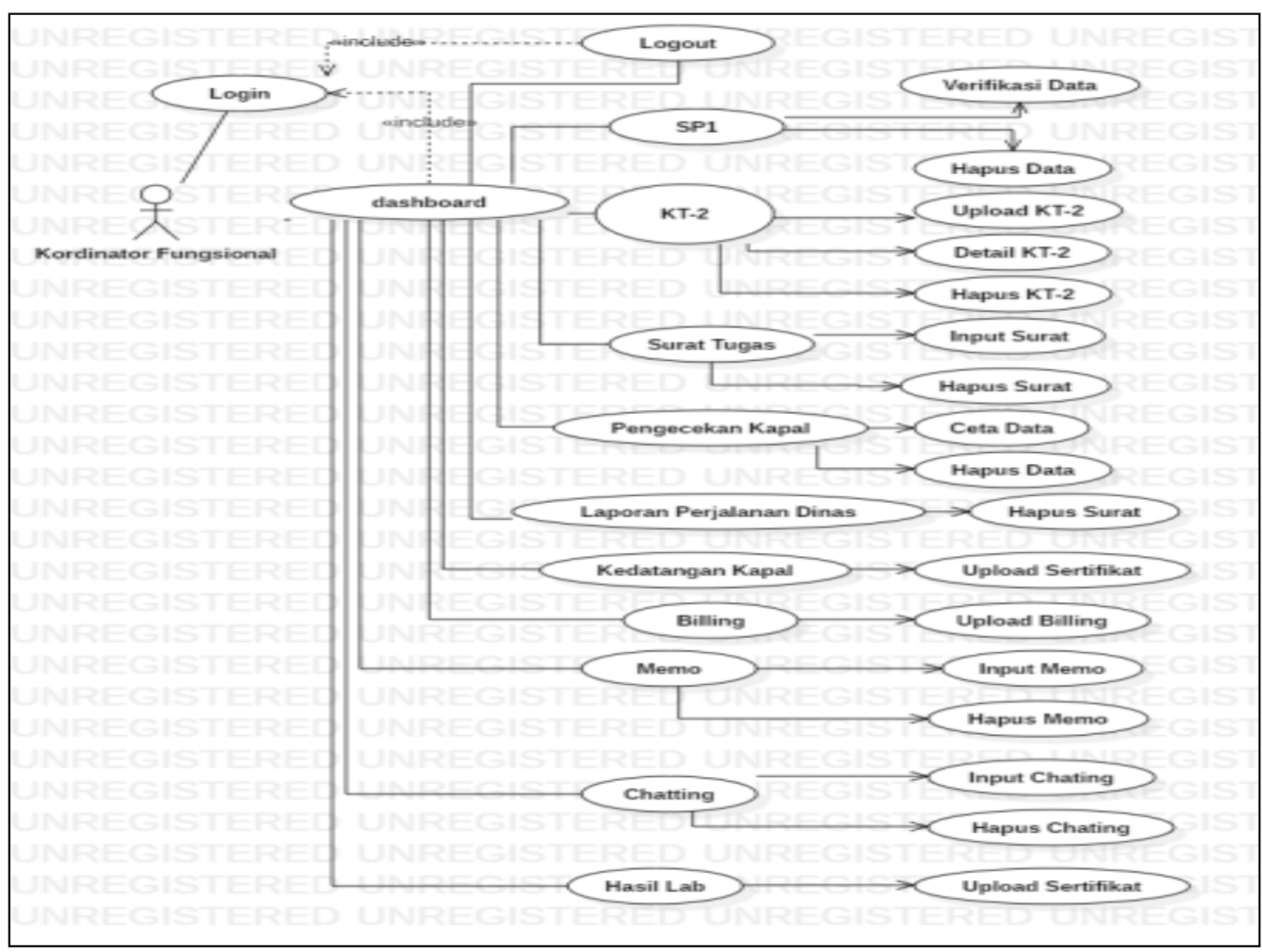

Gambar 5. Use Case Diagram KorFung

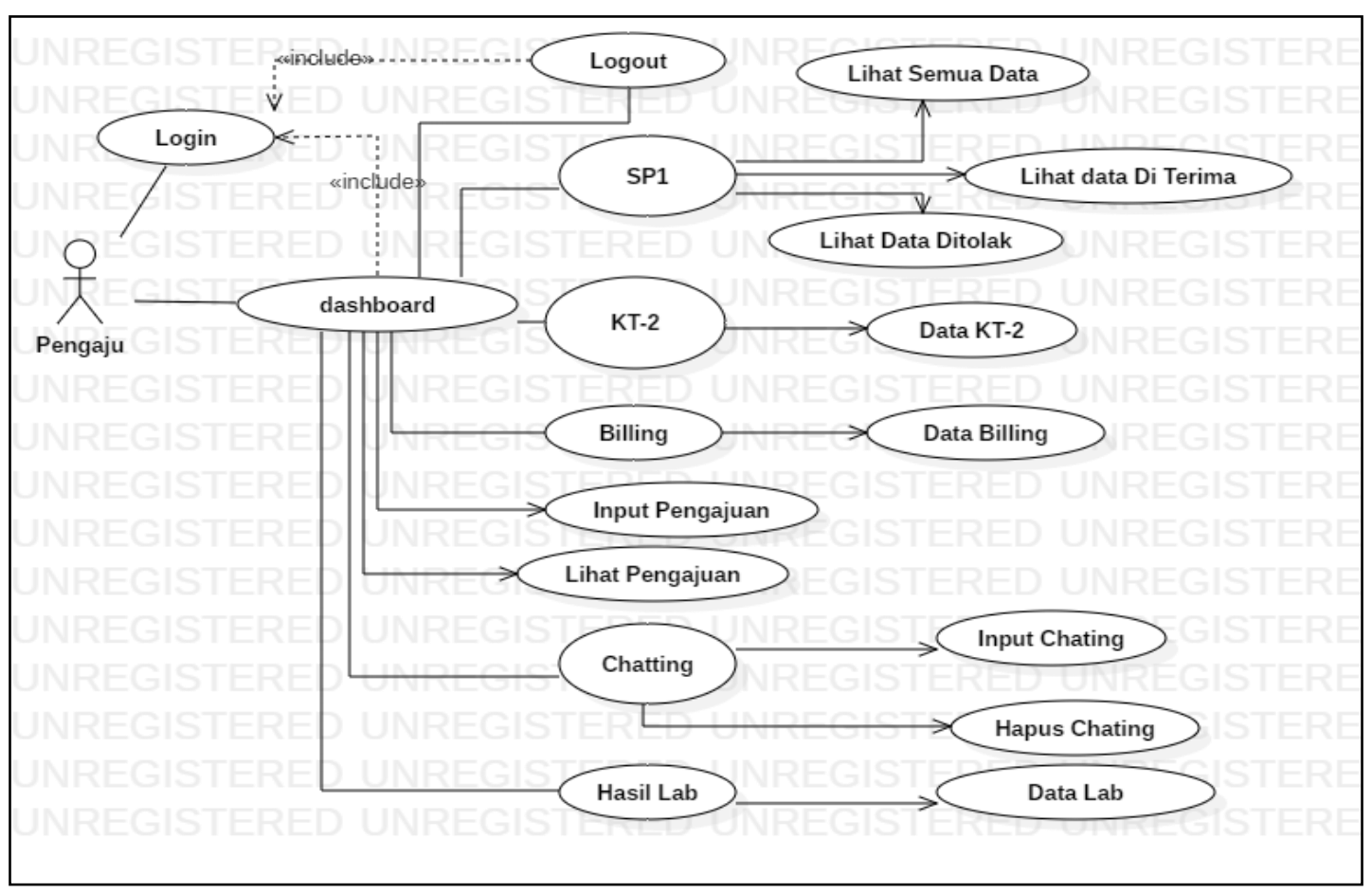

Gambar 6. Use Case Diagram Pemohon 


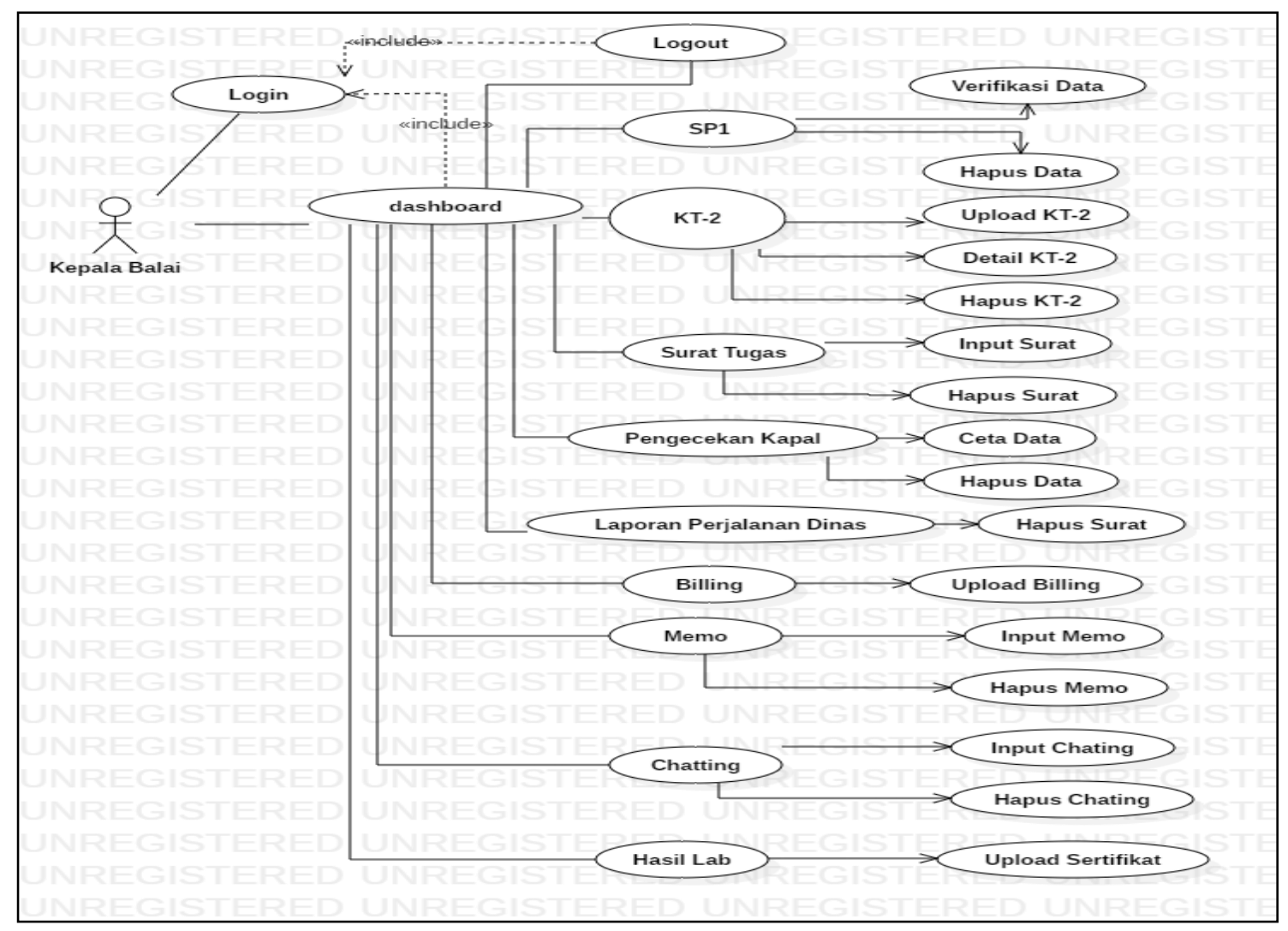

Gambar 7. Use Case Diagram Kepala Balai

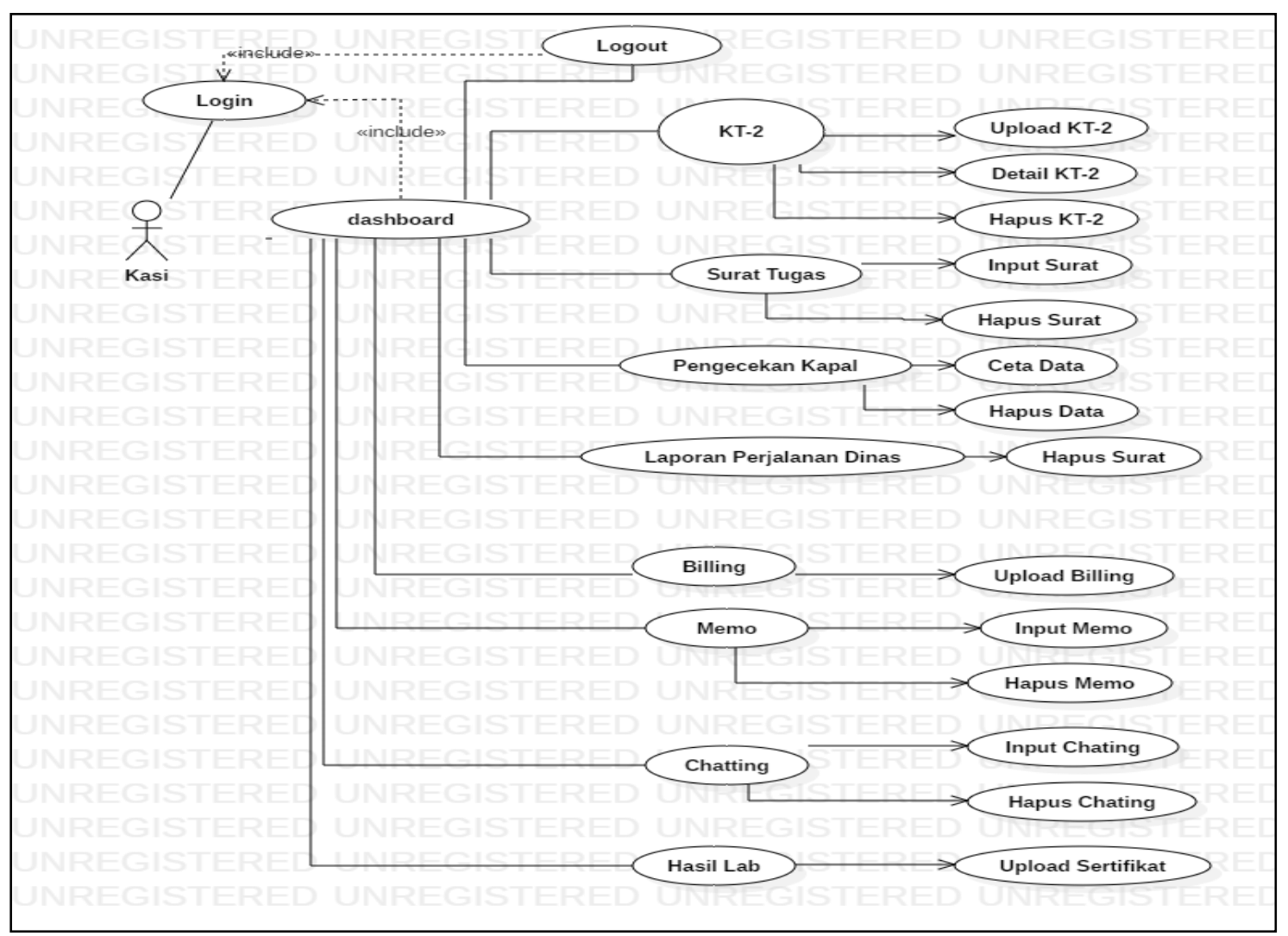

Gambar 8. Use Case Diagram Kasir 


\section{Database}

Pada sistem informasi monitoring pelayanan karantina tumbuhan "SiMERAQ" terdiri dari 16 rancangan tabel database, yaitu : Tabel admin_website, Tabel bayar_billing, Tabel billing, Tabel chat, Tabel chat1, Tabel chat_lapcek, Tabel chat_pesan, Tabel informasi, Tabel kedatangan kapal, Tabel Tabel kt2, Tabel lab, Tabel lap_cek, Tabel pengaju, Tabel peti_kemas, Tabel riwayat_sp1 dan Tabel surat_tugas.

\subsection{Interface}

Antarmuka atau interface merupakan media perantara yang menghubungkan antara sistem dengan pengguna (actor) yang terlibat dalam sistem. Sebelum menjadi antarmuka yang siap digunakan, dilakukan perancangan interface yang bertujuan untuk mengakomodasi keinginan pengguna untuk menggunakan sistem yang dibangun. Ada beberapa prinsip yang digunakan dalam merancang atau mendesain antarmuka bagi pengguna (user interface) [8], yaitu User Competibility, Product Competibility, Task Compatibility, Work Flow Compatibility, Consistency and Familiarty, Control, Flexibility and Responsiveness, Invisible Technology, Robustness, Ease of learning. Antar muka (interface) yang dibuat terdiri dari dua bagian yaitu; antar muka front end untuk masyarakat sebagai user dan antar muka back end untuk administrator website.

\section{Interface Front End (Masyarakat).}

Untuk antar muka front end yang digunakan oleh masyarakat sebagai user dalam hal pengajuan proses karantina tumbuhan, terdiri dari beberapa menu, seperti menua awal adalah menu registrasi sehingga dapat melakukan login atau masuk ke aplikasi yang selanjutnnya dapat melanjutkan proses pengajuan karantina tumbuhan. Gambar 9,10 dan 11 menampilkan menu sebagai antar muka antara user pengusul dengan sistem.

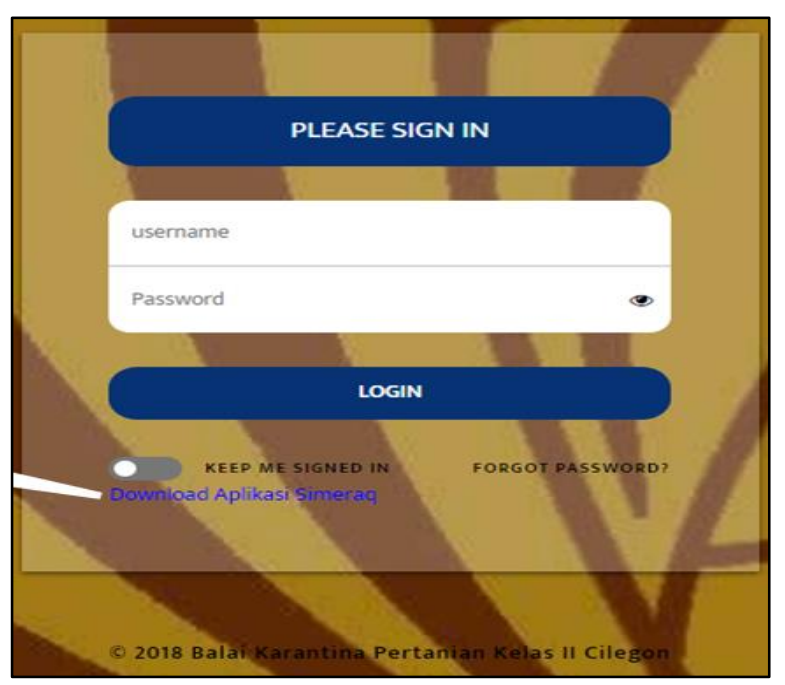

Gambar 9. Halaman Login

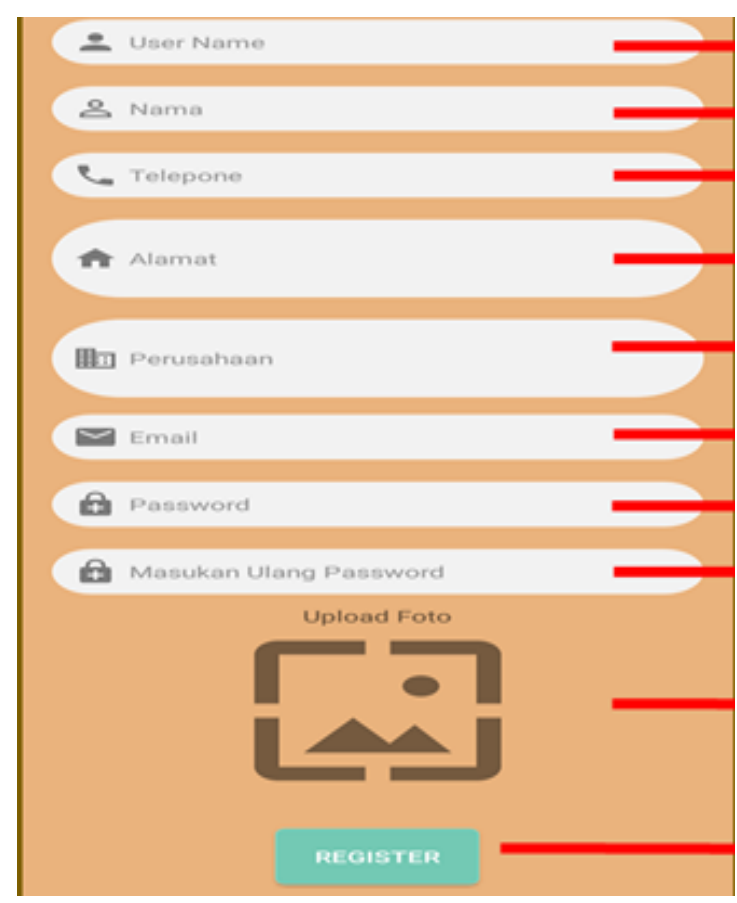

Gambar 9. Halaman Registrasi 


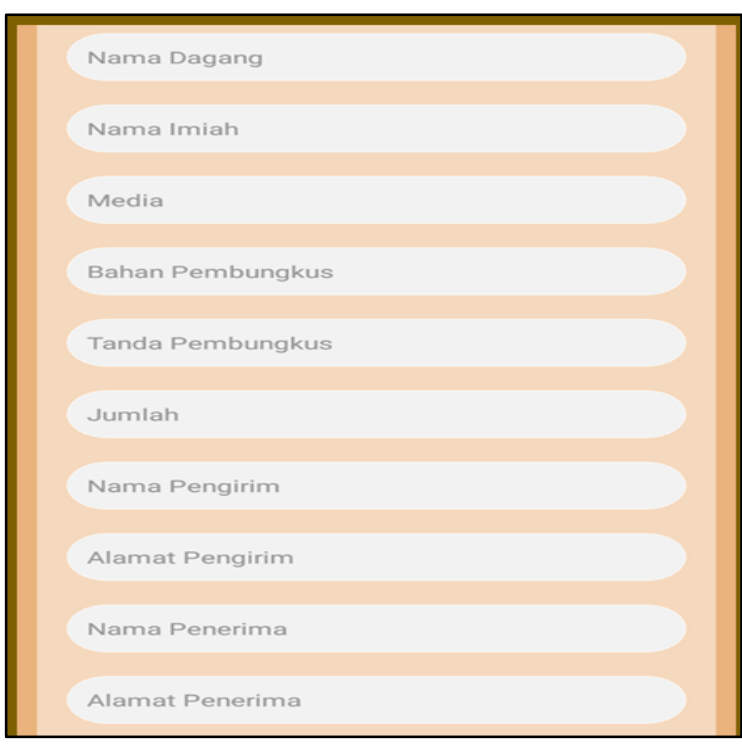

Gambar 11. Halaman Pengajuan

2. Interface Back End (Administrasi).

Antar muka back end sistem informasi monitoring pelayanan karantina tumbuhan berbasis website yang digunakan oleh petugas verifikasi, kasi, korfung, bendahara, laboran, dan kepala balai tersaji pada gambar 12 sampai gambar 18.

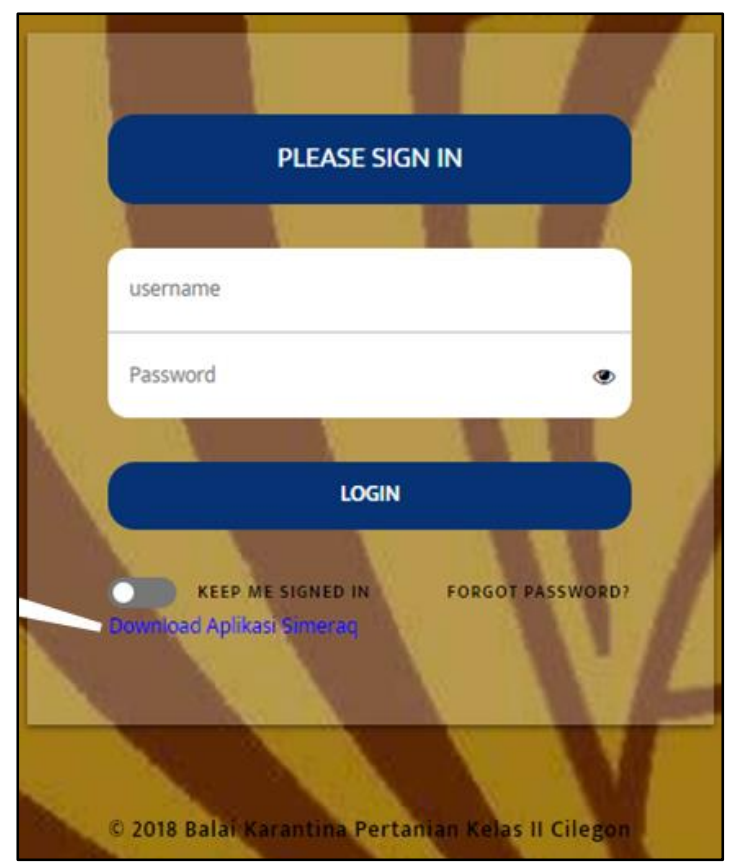

Gambar 12. Halaman Login

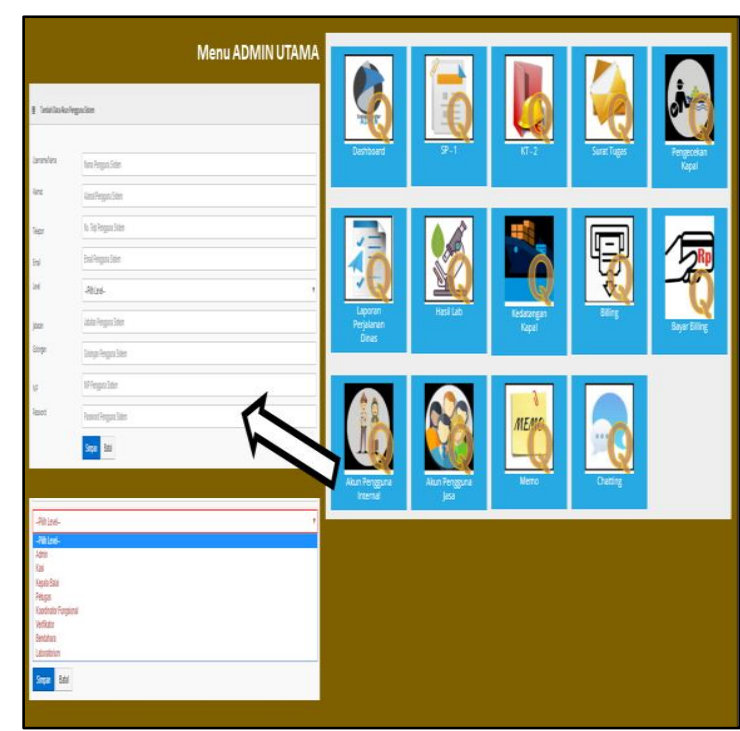

Gambar 13. Halaman Menu Admin

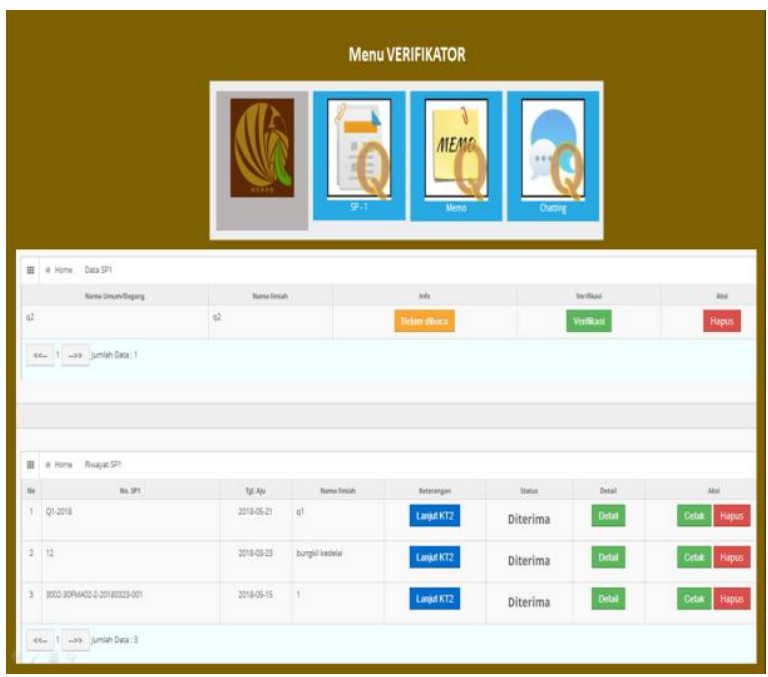

Gambar 14. Menu Verifikator

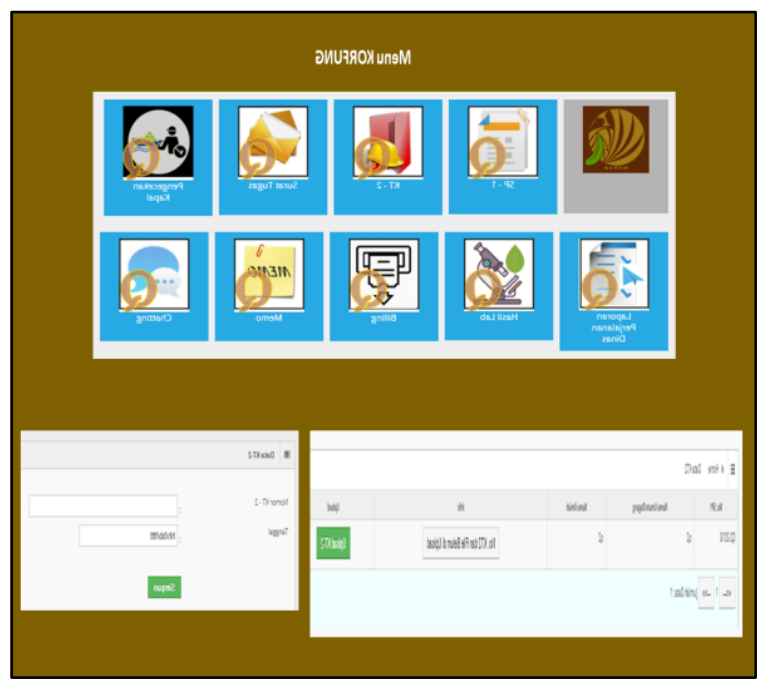

Gambar 15. Menu KorFung 


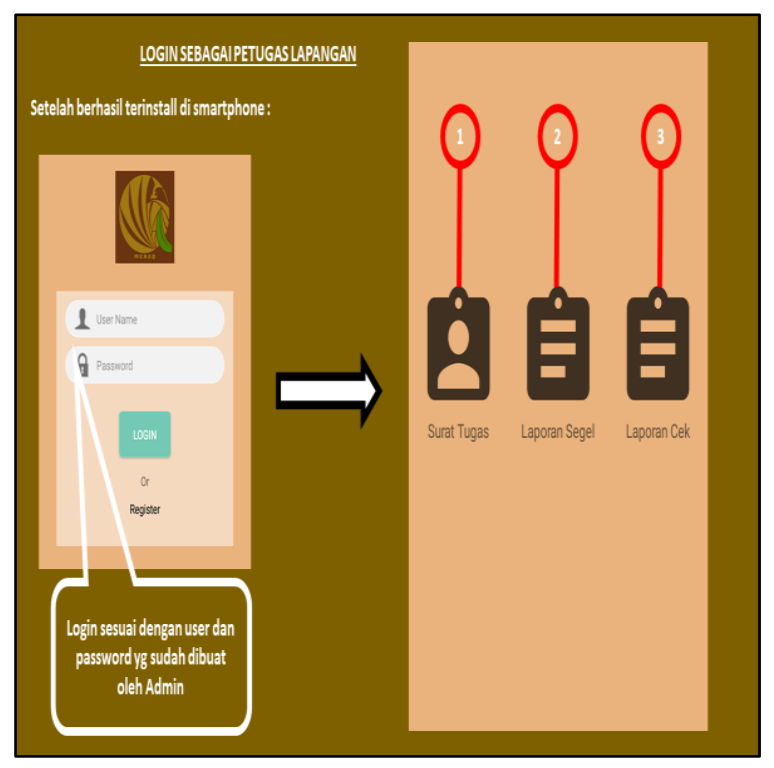

Gambar 16. Menu Petugas Lapangan

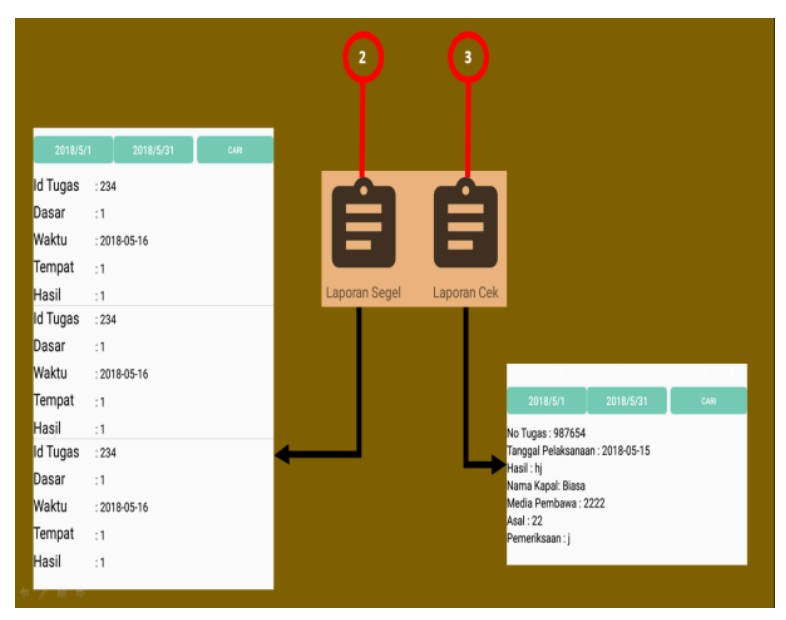

Gambar 17. Menu Laporan

\section{KESIMPULAN}

Hasil penelitian ini adalah rancangan dan prototype sistem informasi monitoring pelayanan karantina tumbuhan "SiMERAQ" yang dapat menunjang suksesnya good governance dan meningkatnya pelayanan prima kepada masyarakat karena dapat lebih efektif, jelas dan cepat dalam mendapatkan informasi. Sehingga akan bermanfaat dalam: Penyajian informasi menjadi lebih uptodate, Efektif dan efisien dalam penyajian kegiatan pelayanan dan adanya sistem ini dapat mempercepat monitoring potensi penyimpangan stakeholder dari persyaratan teknis dan meningkatnya monitoring kegiatan operasional pelayanan karantina tumbuhan baik itu impor, ekspor dan domistik. Selain itu adanya sistem berbasis IT yang dibuat untuk memonitoring pelayanan karantina tumbuhan ini dapat menjadi faktor pendukung dalam peningkatan kualitas SDM, Kualitas pelayanan karena semakin mudah bagi masyarakat dalam memonitoring pengajuan karantina tumbuhan.

\section{DAFTAR PUSTAKA}

[1] Sutabri, Tata. 2012. Analisis Sistem Informasi. Andi. Yogyakarta.

[2] Sutanta, Edhy. Basis Data dalam Tinjauan Konseptual. Yogyakarta: Andi, 2011.

[3] Semil, Nurmah. 2018. Pelayanan Prima Instansi Pemerintah, Prenadamedia Group. Jakarta.

[4] Mudjahidin, Dita Pahang Putra, Nyoman. "Rancang Bangun Sistem Informasi Monitoring Perkembangan Proyek Berbasis Web Studi Kasus di Dinas Bina Marga dan Pemantusan". Jurnal Teknologi Industri. Vol. 11, No. 1, Universitas Muhammadiyah Malang., pp. 75-83, 2010.

[5] Rohayani. Antoni, Darius. Putra, Soekarno. "Pengembangan Perangkat Lunak E-Monitoring Kebersihan Kereta Penumpang Wilayah Divisi Regional III Palembang Berbasis Android". IF.Bina Darma.ac.id. Universitas Bina Darma.

[6] Supardi. 2005. Metode Penelitian Ekonomi dan Bisnis. Yogyakarta: UII Press

[7] Pressman, R.S. 2010. Software Engineering : a practitioner's approach, McGraw-Hill, New York, 68

[8] W.O Galitz., The essential Guide to Unser Interface Design, Canada: John Wiley \& Sons. 2007 